\title{
PENGEMBANGAN METODE OTENTIKASI KEASLIAN IJASAH DENGAN MEMANFAATKAN GAMBAR QR CODE
}

\author{
Eka Ardhianto, S.Kom, M.Cs ${ }^{1}$ \\ Program Studi Teknik Informatika, \\ Fakultas Teknologi Informasi \\ Universitas Stikubank (UNISBANK) \\ Semarang
}

\author{
Nur Wakhidah, S.Kom, M.Cs ${ }^{2}$ \\ Program Studi Teknik Informatika, Fakultas \\ Teknologi Informasi dan Komunikasi \\ Universitas Semarang (USM) \\ Semarang
}

\begin{abstract}
QR Code is two-dimensional image that represents the data, particularly data-shaped teks. $Q R$ Code is an evolution of the first one-dimensional barcode into two dimentions. QR Code has the ability to store much more data than a barcode.

One of the important data in the campus are collegers certificate. It is a document that serves as proof of authenticity that someone has undergone a formal education stage and successfully pass the exam. The collegers certificate conventionally used today is a collegers certificate in physical form so that there is the possibility of lost or damaged. Conventional collegers certificate verification process is difficult because the process is carried out only by the manufacturer of collegers certificate. The means used to verify the authenticity of the data collegers certificate today is to make direct contact to the manufacturer's certificate regarding authenticity certificate holder, as well as the legalization process tertandatangan of collegers certificate maker.

From the conduct of research and testing conducted it can be concluded that: QRCode can be used to accommodate large data information of graduate, Facilitate the detection of the authenticity of the certificate of ownership information from mobile devices, also QRCode can be quickly used to verify the certificates quickly and accurately

Keywords: QR Code, Diploma, Authentication, Ownership
\end{abstract}

\section{PENDAHULUAN}

Teknologi informasi memberikan pengaruh yang sangat besar pada kehidupan manusia hampir di setiap bidang kehidupan.Contohnya adalah pada bidang pelayanan perpustakaan dan pelayanan akademik mahasiswa, dengan diterapkannya teknologi informasi terbukti meningkatkan efektifitas dan efisiensi kerja. Salah satu teknologi yang sudah pernah dikembangkan dan diterapkan di adalah penggunaan barcode.

Pada masa ini, penggunaan barcode sudah tidak asing lagi. Hal ini adalah untuk memudahkan dalam mengelola inventori yang mereka miliki, karena barcode ini dapat menyimpan data spesifik sebagai contoh adalah data anggota perpustakaan yang meliputi kode buku, nomor identitas, nama dan lain-lain sehingga sistem komputer dapat mengidentifikasi informasi yang dikodekan dalam barcode dengan mudah. Seiring dengan perkembangan teknologi yang begitu pesatnya, penggunaan barcode kini mulai digantikan dengan QR Code.

QR Code adalah image dua dimensi yang merepresentasikan suatu data, terutama data berbentuk teks.QR Code merupakan evolusi dari barcode yang awalnya satu dimensi menjadi dua dimensi.QR Code memiliki kemampuan menyimpan data yang lebih jauh besar daripada barcode.

Saat ini penggunaan QR Code sudah cukup luas.Banyak Negara di dunia, terutama Jepang, telah menerapkan teknologi QR Code pada perindustriannya. Sementara di Indonesia, QR Code sudah diterapkan pada beberapa perusahaan. Salah satunya adalah pada surat kabar Kompas, yang mengklaim sebagai pelopor penggunaan QR Code di Indonesia, yang diterbitkan oleh Kelompok Kompas Gramedia. Hal ini terlihat pada surat kabar tersebut dimana terdapat QR Code yang merepresentasikan artikel pada surat kabar tersebut. Contoh lain penggunaan QR Code adalah digunakan sebagai salah satu metode pengamanan data atau sekuriti data.

Salah satu data penting dalam kampus adalah ijasah. Ijazah merupakan suatu dokumen yang berfungsi sebagai bukti autentik bahwa seseorang telah menjalani tahap pendidikan secara formal dan berhasil lulus ujian. Ijazah konvensional yang digunakan sekarang adalah ijazah berbentuk fisik sehingga ada kemungkinan ijazah tersebut hilang atau rusak. Proses verifikasi ijazah konvensional sulit dilakukan karena proses tersebut hanyadapat dilakukan oleh pembuat ijazah. Cara yang digunakan untuk melakukan verifikasi keaslian data ijasah saat ini adalah dengan melakukan kontak langsung kepada pembuat ijasah mengenai keaslian pemegang ijasah, serta adanya proses legalisasi tertandatangan dari pembuat ijasah.

Oleh karena itu, pada penelitian ini akan dikembangkan pengembangan penggunaan QR Code sebagai salah satu metode autentikasi.

\section{TUJUAN DAN MANFAAT}

Suatu penelitian tidak terlepas dari suatu goal atau tujuan akhir yang nantinya diharapkan dapat menghasilkan suatu manfaat yang dapat digunakan baik bagi seorang pribadi, suatu kelompok, komunitas atau khalayak umum.

Tujuan dari penelitian ini adalah mengimplementasikan penggunaan $\mathrm{QR}$ Code untuk 
melakukan autentikasi kebenaran kepemilikan ijasah. Berkaitan dengan hasil yang dimaksudkan manfaat yang diharapkan adalah adanya suatu metode baru dan atau metode tambahan yang digunakan dapat menghasilkan informasi keyakinan untuk mendetaksi keaslian ijasah.

\section{a. Definisi Citra Digital}

Menurut kamus Webster, citra adalah suatu representasi, kemiripan, atau imitasi dari suatu objek atau benda.Citra dapat dikatakan sebagai citra digital jika citra tersebut disimpan dalam format digital (dalam bentuk file).Hanya citra digital yang dapat diolah menggunakan komputer. Jenis citra lain jika akan diolah dengan komputer harus diubah dulu menjadi citra digital. [10]

Sebuah citra digital dapat mewakili oleh sebuah matriks yang terdiri dari $\mathrm{M}$ kolom $\mathrm{N}$ baris, dimana perpotongan antara kolom dan baris disebut piksel (pixel $=$ picture element), yaitu elemen terkecil dari sebuah citra. Piksel mempunyai dua parameter, yaitu koordinat dan intensitas atau warna. Nilai yang terdapat pada koordinat $(\mathrm{x}, \mathrm{y})$ adalah $\mathrm{f}(\mathrm{x}, \mathrm{y})$, yaitu besar intensitas atau warna dari piksel di titik itu. Oleh sebab itu, sebuah citra digital dapat ditulis dalam bentuk matriks pada gambar 1. [10]

$$
f(x, y)=\left[\begin{array}{cccc}
f(0,0) & f(0,1) & \ldots & f(0, M-1) \\
f(1,0) & \ldots & \ldots & f(1, M-1) \\
\ldots & \ldots & \ldots & \ldots \\
f(N-1,0) & f(N-1,1) & \ldots & f(N-1, M-1)
\end{array}\right]
$$

Gambar 1.

\section{Matriks citra digital $\mathbf{N} \times \mathbf{M}$}

\section{b. Representasi Citra Digital}

Data pada sebuah gambar citra digital direpresentasikan dengan sebuah matriks nxn dimana $n$ sesuai dengan ukuran pikselnya.Misalkan apabila sebuah citra memiliki jumlah piksel 50 x 50, maka citra tersebut dapat direpresentasikan dengan matriks berukuran $50 \times 50$. Setiap elemen matriks merupakan bit-bit warna penyusun piksel tersebut [10]. Contoh representasi citra digital dapat dilihat pada gambar 2 .

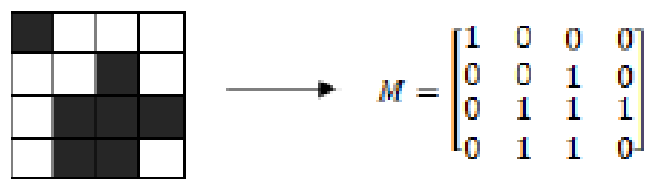

\section{Gambar 2. Representasi citra digital dengan matriks}

Gambar 2. merupakan ilustrasi citra digital hitam-putih dengan ukuran $5 \times 5$ piksel. Didefinisikan bahwa bit " 0 " merepresentasikan piksel putih sedangkan bit "1" merepresentasikan piksel hitam. Untuk citra digital berwana, masing-masing bit merepresentasikan setiap komponen warna pembentuk warna piksel.

\section{c. Warna Pada Cita Digital}

Ada beberapa jenis pewarnaan pada citra digital, yaitu warna hitam-putih (black and white), grayscale, dan citra berwarna. Citra hitam putih disebut juga citra satu bit, karena satu piksel hanya perlu direpresentasikan dengan satu bit data. Namun dari segi kualitas kurang baik karena hanya terdiri dari dua warna, hitam dan putih. [9]

Pada pewarnaan grayscale, warna yang tersedia hanyalah warna diantara hitam dan putih.Oleh karena itu tidak terlalu banyak warna yang ditampilkan pada citra grayscale.Namun kualitas yang dihasilkan lebih baik daripada citra warna hitam putih.Pada pewarnaan grayscale, perubahan warna antara dua piksel yang berdekatan tidak terlihat signifikan sehingga gambar lebih mudah dicerna.

\section{d. QR Code}

QR-Code merupakan teknik yang mengubah data tertulis menjadi kode-kode 2-dimensi yang tercetak ke dalam suatu media yang lebih ringkas.QR-Code adalah barcode 2-dimensi yang diperkenalkan pertama kali oleh perusahan Jepang Denso-Wave pada tahun 1994. Barcode ini pertama kali digunakan untuk pendataan invertaris produksi suku cadang kendaraan dan sekarang sudah digunakan dalam berbagai bidang. QR adalah singkatan dari Quick Response karena ditujukan untuk diterjemahkan isinya dengan cepat. QR-Code merupakan pengembangan dari barcode satu dimensi, QR-Code salah satu tipe dari barcode yang dapat dibaca menggunakan kamera handphone.

QR-Code mampu menyimpan semua jenis data, seperti data angka/numerik, alphanumerik, biner, kanji/kana.Selain itu QR-Code memiliki tampilan yang lebih kecil daripada barcode.Hal ini dikarenakan QR-Code mampu menampung data secara horizontal dan vertikal, jadi secara otomatis ukuran dari tampilannya gambar QR-Code bisa hanya seperspuluh dari ukuran sebuah barcode.Tidak hanya itu QR-Code juga tahan terhadap kerusakan, sebab QRCode mampu memperbaiki kesalahan sampai dengan 30\% tergantung dengan ukuran atau versinya.Oleh karena itu, walaupun sebagian simbol QR-Code kotor ataupun rusak, data tetap dapat disimpan dan dibaca. Tiga tanda berbentuk persegi di tiga sudut memiliki fungsi agar simbol dapat dibaca dengan hasil yang sama dari sudut manapun. [7]. 

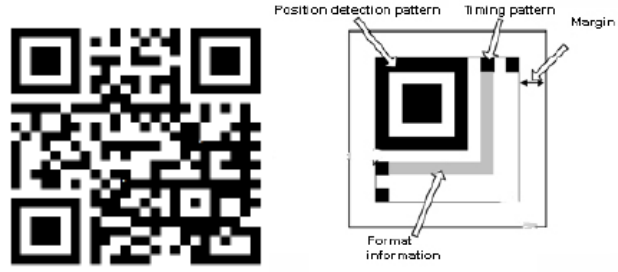

Gambar 3. Contoh QR Code dan Detail QR Code

Dari model seperti gambar 3. dapat dijelaskan secara rinci adalah sebagai berikut :Position detection patterns: Posisi pola deteksi diatur pada tiga sudut kode QR, Posisi dari kode QR terdeteksi dengan pola deteksi posisi yang memungkinkan kecepatan tinggi membaca dan dapat dibaca dari segala arah. Margin: Ini adalah area kosong di sekitar kode QR dan membutuhkan margin sebesar empat modul. Timing pattern: Modul putih dan modul hitam diatur secara bergantian untuk menentukan koordinat, Pola waktu ditempatkan di antara dua pola deteksi posisi dalam kode QR. Format Information: Informasi Format dibaca pertama ketika kode tersebut diterjemahkan.

Seiring berkembangnya QR Code, semakin banyak penelitian yang dilakukan mengenai kode simbol ini.Berbagai penelitian terus dilakukan, baik untuk menambah jumlah data yang dapat disimpan dalam QR Code, menambah resistensi terhadap kerusakan, dan lain-lain. Beberapa penelitian yang telah dilakukan diantaranya adalah :

1. Pembuatan aplikasi pembacaan QR Code menggunakan perangkat mobile berbasis $\mathrm{J} 2 \mathrm{ME}$ [1]. Pada penelitian ini dibuat aplikasi pembaca QR Code menggunakan perangkat mobile berbasis sistem operasi J2ME dengan kamera digital yang terintegrasi pada mobile tersebut.Pada penelitian ini juga dianalisis tingkat akurasi pembaca QR Code tersebut sehingga ditemukan parameter yang mempengaruhi tingkat akurasinya.

2. QR Code untuk tandatangan digital [2].Pada penelitian ini, peneliti menggunakan QR Code untuk tanda tangan digital. Data yang diencode adalah message digest dari artikel atau tulisan yang akan dibuat tanda tangan digitalnya. Pada penelitian ini juga dibuat sebuah perangkat lunak yang langsung mengenerate QR Code dari masukan berupa tulisan/artikel yang akan dibuat tanda tangan digiltalnya.

3. QR Code untuk autentikasi novel user [5].Pada penelitian ini, QR Code digunakan sebagai autentikasi user pada sebuah jaringan internet untuk mobile phone.

\section{e. Versi Pada QR Code}

Versi simbol QR-Code berkisar dari Versi 1 ke Versi 40. Setiap versi memiliki konfigurasi modul yang berbeda atau jumlah modul (Modul ini mengacu pada titik-titik hitam dan putih yang membentuk QR-Code). "Konfigurasi Modul" mengacu pada jumlah modul yang terkandung dalam simbol, dimulai dengan Versi 1 (21 x 21 modul) sampai ke Versi 40 (177 x 177 modul).Setiap nomor versi lebih tinggi terdiri dari 4 modul tambahan per samping seperti terlihat pada gambar 4.

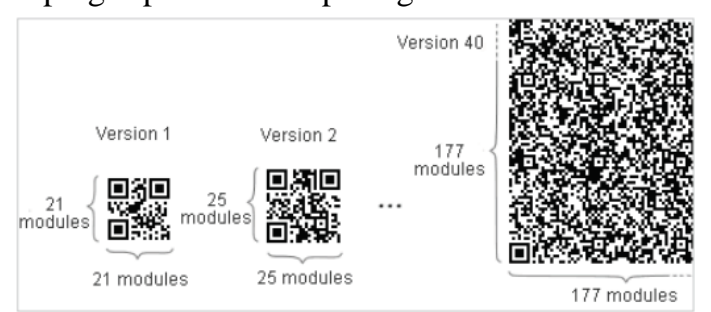

Gambar 4. Versi Simbol QR Code

Setiap versi simbol QR-Code memiliki kapasitas data yang sesuai dengan jumlah data, jenis karakter dan tingkat kesalahan koreksi.Untuk pemeriksaan data dengan kapasitas maksimum ditentukan pada setiap versinya. Untuk versi dan kapasitas data maksimum, maka jumlah data dan modul akan meningkat sehingga simbol QR-Code semakin besar. [14]

\section{f. Koreksi Kesalahan Pada QR Code}

QR Code memiliki kemampuan mengoreksi kesalahan untuk mengembalikan data jika kode kotor atau rusak.Empat tingkat kesalahan koreksi yang tersedia bagi pengguna, tingkatan ini mampu mengoreksi kesalahan pada QR-Code Faktor lingkungan dan ukuran QR-Code perlu dipertimbangkan untuk mengetahui tingkat kesalahan. Tingkat $\mathrm{Q}$ atau $\mathrm{H}$ dapat dipilih jika kondisi lingkungan kotor yang akan menyebabkan QR-Code mengalami kerusakan, sedangkan tingkat $\mathrm{L}$ dapat dipilih jika kondisi lingkungan bersih dengan jumlah data yang besar. Tingkat $\mathrm{M}$ adalah tingkat yang paling sering digunakan.Tabel 1. adalah berisi tentang koreksi kesalahan QR-Code. [14]

Tabel 1. Koreksi Kesalahan pada QR Code

\begin{tabular}{|l|l|}
\hline \multicolumn{2}{|c|}{ Kapasitas koreksi kesalahan QR-Code } \\
\hline Level L & Dapat Mengoreksi Kesalahan Sampai 7\% \\
\hline Level M & Dapat Mengoreksi Kesalahan Sampai 15\% \\
\hline Level Q & Dapat Mengoreksi Kesalahan Sampai $25 \%$ \\
\hline Level H & Dapat Mengoreksi Kesalahan Sampai 30\% \\
\hline
\end{tabular}

\section{METODE PENELITIAN}

Metode penelitian yang digunakan untuk melakukan pemngembangan metode otentikasi keaslian ijasah dengan memanfaatkan gambar QR code adalah dengan menggunakan model prototipe sebagai metode pengembangan perangkat lunak (software). 
Model pengembangan perangkat lunak dengan model prototipe ini akan menghasilkan sebuah aplikasi dalam bentuk prototipe sebelum aplikasi tersebut memasuki tahap design. Dalam fase ini, prototype yang telah dirancangakan dievaluasi. Tahap ini akanterus menerus diulang sampai aplikasi cukup sesuai dengan keinginan. Apabila prototype telah selesai, maka tahapan aplikasi akankembali berlanjut ketahap design. Gambar 4.1 menjelaskan bagaimana urutan proses pengembangan perangkat lunak dengan model prototype.

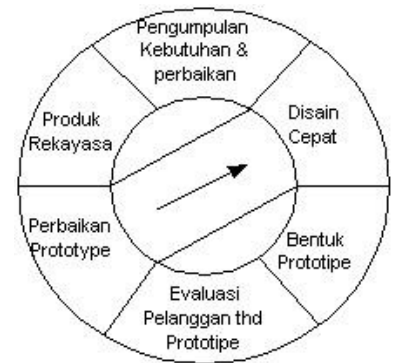

Gambar 5. Prototyping Method [12]

\section{HASIL DAN PEMBAHASAN}

\section{a. Bahan Penelitian}

Penelitian ini menggunakan bahan inputan berupa ijasah mahasiswa yang telah lulus untuk diambil data berupa Nomer Seri Ijasah, Nama, NIM, Tempat dan Tanggal Lahir Fakultas, Program Studi, Jenjang, Tahun Masuk, Tahun Lulus, Nama Dekan, Nama Rektor seperti terlihat pada gambar 6. dan tabel 2. untuk Analisis kebutuhan input.

Tabel 2. Analisis Kebutuhan Input

\begin{tabular}{|c|c|}
\hline Nama & Data Ijasah \\
\hline Deskripsi & Ijasah Alumni \\
\hline Struktur data & $\begin{array}{l}\text { Nomer Seri Ijasah + } \\
\text { Nama + NIM + Tempat } \\
\text { Lahir + Tanggal Lahir + } \\
\text { Fakultas + Program } \\
\text { Studi + Jenjang + Tahun } \\
\text { Masuk + Tahun Lulus + } \\
\text { Nama Dekan + Nama } \\
\text { Rektor }\end{array}$ \\
\hline Nomer Seri & Numeric \\
\hline Ijasah & Alfanumerik \\
\hline Nama & Alfanumerik \\
\hline NIM & Alfanumerik \\
\hline Tempat & Alfanumerik \\
\hline Lahir & \\
\hline Tanggal & Alfanumerik \\
\hline Lahir & \\
\hline Fakultas & Alfanumerik \\
\hline Program & \\
\hline Studi & Alfanumerik \\
\hline Jenjang & Alfanumerik \\
\hline Tahun & \\
\hline Masuk & Alfanumerik \\
\hline Tahun Lulus & Alfanumerik \\
\hline
\end{tabular}

\begin{tabular}{|l|l|}
\hline Nama Dekan & Alfanumerik \\
Nama Rektor & Alfanumerik \\
\hline
\end{tabular}

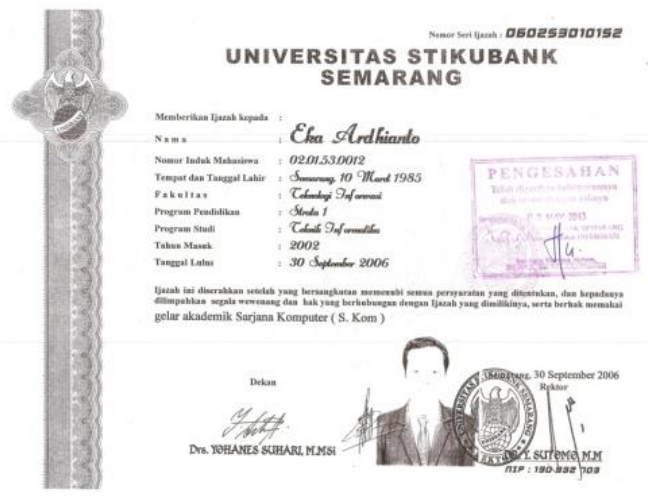

Gambar 6. Contoh scan ijasah

\section{b. Pemilihan Perangkat Lunak Dan Perangkat Keras}

Dalam melakukan implementasi dan pengkonstruksian aplikasi dari mode rancangan menjadi sebuah aplikasi jadi, pada penelitian ini menggunakan perangkat QR Generator dengan bahasa PHP dan Aplikasi QR Reader yang terpasang pada perangkat mobile.

\section{c. Alur Algoritma}

Alur perancangan algoritma yang digunakan untuk membuat aplikasi ini adalah dengan melakukan tahapan pembuatan aplikasi dalam bentuk prototype untuk melakukan generate gambar qr code dari database alumni dan membaca qr code dengan memanfaatkan aplikasi QR Reader yang terpasang pada perangkat mobile.

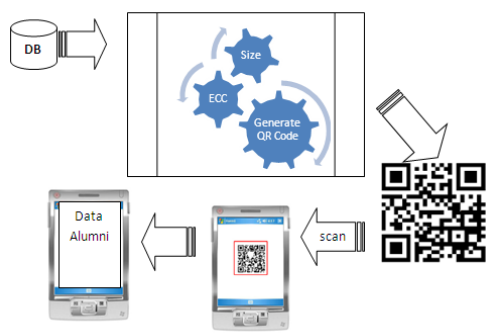

\section{Gambar 7. Gambaran umum proses generate dan pembacaan QR Code}

Secara garis besar proses yang terlihat pada Gambar 7 ada 2 macam yaitu : Proses pembangkitan QR Code dan Proses pembacaan QR Code.

\section{1) Perancangan Pembangkitan QR Code}

Pada proses pembangkitan gambar QR code, input yang digunakan adalah data alumni yang tersimpan pada database dengan urutan struktur data seperti terlihat pada table 2, sedangkan gambar 8 adalah bentuk gambaran alur pembangkitan gambar QR code. 


\section{Hasil}

Citra hasil pengolahan akan disimpan pada seuah folder dengan nama yang unik sehingga akan dapat dipanggil sesuai dengan urutan data alumni, bentuk tampilan hasilnya dapat dilihat pada gambar 11.

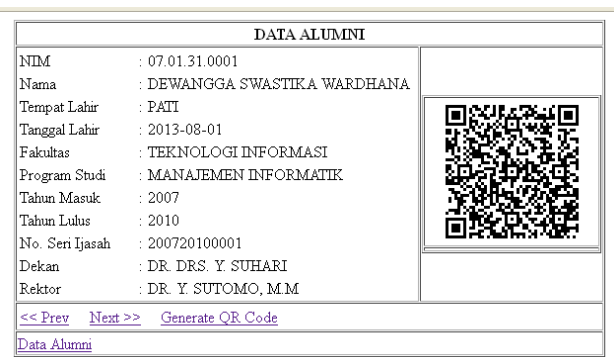

Gambar 11. Bentuk tampilan data Alumni yang dengan QR Code

Seperti yang terlihat pada gambar 11, gambar QR Code yang memiliki informasi yang relevan dengan data alumni diambil dari direktori khusus hasil dari penyimpanan file gambar QR Code yang telah dihasilkan pada proses QR Generate sebelumnya. Bentuk source codenya dapat dilihat pada tabel 5.

Tabel 5. Source Code Tampilan Data Alumni

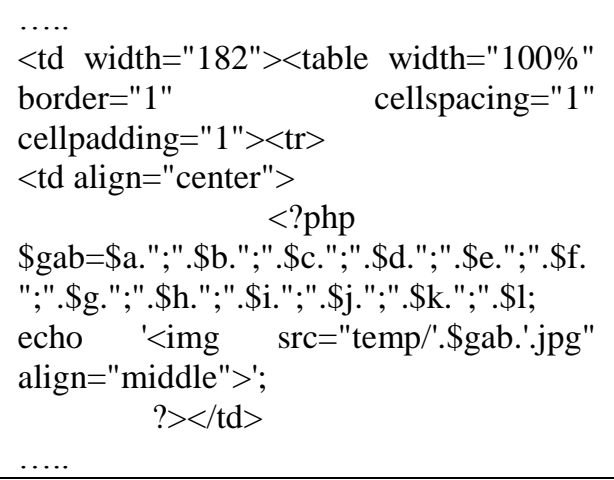

\section{2) Perancangan Pembacaan QR Code}

Perancangan sistem Pembacaan QR Code ini memanfaatkan aplikasi QR Reader yang terpasang pada perangkat mobile sehingga dapat mengubah data dari bentuk Gambar QR Code menjadi data alumni.

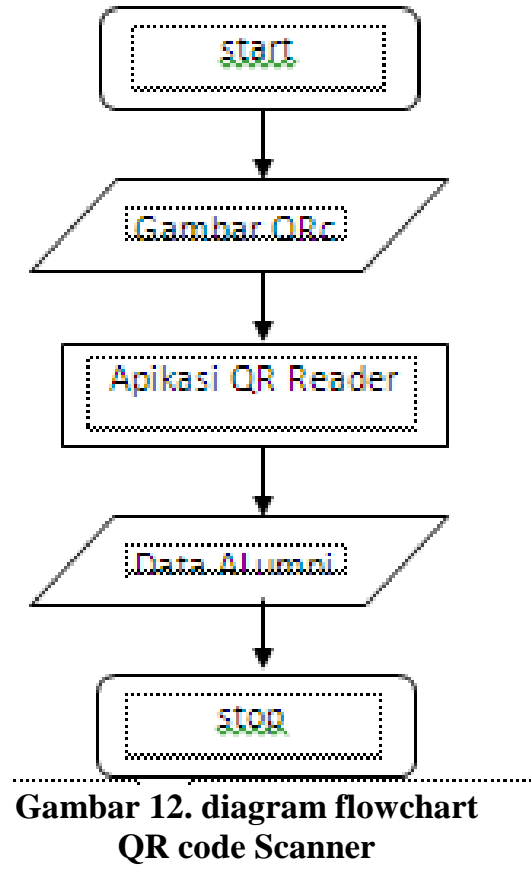

Berdasarkan gambar 12 diagram flowchart QR Code Scanner terdiri dari beberapa bagian sebagai berikut :

1. Pengambilan Gambar dari Webcam

Proses pengambilan gambar ini sistem akan memanfaatkan webcam yang akan menjadikan Gambar QR Code sebagai inputan.

2. Pembacaan dengan QR Reader

Inputan yang berupa gambar QR Code akan di baca sehingga menghasilkan informasi tentang data alumni yang sesuai dengan data awal.

\section{KESIMPULAN}

Dari pelaksanaan penelitian dan pengujian yang dilakukan dapat ditarik kesimpulan yaitu :

1. QRCode dapat digunakan untuk menampung informasi data alumni yang besar.

2. Mempermudah pendeteksian keaslian informasi kepemilikan ijazah melaluiperangkat mobile.

3. QRCode dapat digunakan dengan cepat untuk menverifikasi Ijazah dengan cepat dan akurat. 


\section{DAFTAR PUSTAKA}

[1] Rahayu, Yeni Dwi, dkk. 2006. Pembuatan Aplikasi Pembacaan Quick Response Code Menggunakan Perangkat Mobile Berbasis J2ME Untuk Identifikasi Suatu Barang. Surabaya: Politeknik Elektronika Negeri Surabaya Institut Teknologi Sepuluh Nopember.

[2] Suryadi, Dedi. Teknologi Informasi dalam Sistem Informasi Manajemen (SIM) Pendidikan Menengah Kejuruan. Bandung: FTPK UPI.

[3] ISO/IEC 18004. 2000. Information Technology - Automatic Identification and Data Capture Techniques - Bar Code Symbology - QR Code. Swizerland : International Standard

[4] Adha, Ripandy. 2010. Message Digest dalam bentuk QRCode Sebagai Tanda Tangan Digital. Bandung: ProgramStudi Teknik Informatika STEI ITB.

[5] Kuan, Chieh Liao \& Hsun Lee Wei. 2010. A Novel UserAuthentication Scheme Based on QR-Code. Taichung,Taiwan: Journal of Networks, Vol.5, No.8. pp937-941.

[6] Rulez, Shinigami. 2011. Pengolahan Citra Digital diambil dari http://shinigamirulez.blogspot. com/2009/01/pengolahancitra-digital.html

[7] Denso Wave. 2010. QR Code Introduction SymbolVersion. Di http://www.densowave.com /QRCode/QRgene2-e.html

[8] Castleman K.R. (1996). Digital image processing. New Jersey : Prentice Hall.

[9] http://asanisembiring.files.wordp ress .com/2012/02/operasi-operasi-dasarpengolahan-citradijital.pdf. Akses tanggal 28 Januari 2013

[10] http://informatika.stei.itb.ac.id/ rinaldi.munir/Buku/Pengolahan $\% 20 \mathrm{Citra} \% 2$ 0Digital/Bab4_Operasioperasi\%20Dasar\%20 Pengolahan\%20Citra\%20Dijital.pdf. akses tanggal 28 Januari 2013

[12] Pressman, Roger S.(2002) Rekayasa Perangkat Lunak : Pendekatan Praktisi (Buku 1), Andi, Yogyakarta

[13] Putra, Darma. 2010. Pengolahan Citra Digital, Andi, Yogyakarta

[14] www.thonky.com/qr-code-tutorial 